\title{
THE EFFECT OF PHILANTHROPIC RESPONSIBILITY ON COMPETITIVENESS OF PRIVATE UNIVERSITIES IN NIGERIA
}

\author{
Oluwakemi O. Onayemi ${ }^{1}$, Chinonye L. Moses ${ }^{2}$, Omotayo A. Osibanjo ${ }^{3}$, Marvellous \\ A.C Gberevbie ${ }^{4}$, Oluwatosin 0 . Onayemi ${ }^{5}$
}

\author{
${ }^{1}$ Covenant University, Ogun State, Nigeria, Oluwakemi.onayemipgs@stu.cu.edu.ng \\ ${ }^{2}$ Covenant University, Ogun State, Nigeria, chinonye.moses@covenantuniversity.edu.ng \\ ${ }^{3}$ Covenant University, Ogun State, Nigeria, ade.osibanjo@covenantuniversity.edu.ng \\ ${ }^{4}$ Covenant University, Ogun State, Nigeria, Marvelous.gberevbiepgs@stu.cu.edu.ng \\ ${ }^{5}$ Covenant University, Ogun State, Nigeria, onayemitosine@yahoo.com
}

\begin{abstract}
This paper examined the effect of philanthropic responsibility on competitiveness of private universities in Nigeria. The study population consists of 6 private universities in Southwest, Nigeria namely; Covenant University, Babcock University, Bowen University, Redeemers University, Mountain Top University, Afe Babalola University. The sample size was made up of 410 staff of selected universities which were selected based on stratified, random and convenient sampling techniques. In order to obtain relevant data for the study, a well-structured questionnaire was used as an instrument. Out of the 410 questionnaires distributed, a total of 353 were retrieved and duly analyzed. Data analysis was carried out with the aid of Partial Least Square/Structural Equation Modelling and statistical package for social sciences (SPSS) software. The findings showed that philanthropic responsibility has a significant effect on competitiveness of private universities in Nigeria. The study recommends that educational institutions should ensure they engage in Philanthropic responsibilities in order to foster competitiveness which ultimately leads to educational performance.
\end{abstract}

Keywords: Philanthropic responsibility, Competitiveness, Educational Performance

\section{INTRODUCTION}

In Nigeria, the competitiveness of educational institutions has been on a steady decline for many years thereby having a negative effect on Nigerians both psychologically and economically. Also the effect of the COVID-19 pandemic has worsened the issue as most educational institutions both public and private were adversely affected thereby putting a hold on educational activities in the nation.

Educational institutions today can be appraised on developmental continuum with respect to how profoundly they are incorporating corporate social responsibility into strategy and day to day setups all around the world. Educational institutions whose activities generates positive reactions from both internal and external environment are said to be socially responsible, the participation and the growth of social responsibility undertakings have consequently become definite activities of educational institutions desiring to attract a satisfactory degree of economic and shared prominence on long and medium term competitiveness (Brin, Nehme and Polančič 2020). 
Corporate responsibility is acknowledged as a determining factor of competitive performance (Boehe \& Cruz, 2010; Ganiyu, 2017; Motilewa \& Worlu, 2015), however, to our knowledge, the supposed relationship is yet to be verified among Nigerian institutions.

In recent times, one thing that drives corporate social responsibility is corporate philanthropic practices (Igbekoyi, 2017). Philanthropic practices have to do with the act of an organization, corporation or institutions promoting welfare of others (customers, employees, shareholders, community and the environment at large). This involves organizations promoting the wellbeing of others, generally through charitable donations of funds or time (Shabbir \& Wisdom, 2020). Being committed to charitable donations and host environmental education events for the community can increase the name recognition and reputation of a brand or company among stakeholders which will ultimately lead to competitiveness (Motilewa \& Worlu, 2015).

In Nigeria, some institutions have built some impactful programmes designed to be beneficial to the community, and a whole lot of institutions are yet to develop an impressive offering of gestures to benefit its people (Oyewumi, Ogunberu \& Oboh, 2018). Despite the efforts of government in encouraging philanthropic actions that serve the needs of individuals, families, communities, and society, what still remains unclear and worthy of investigation is how discretionary (philanthropic) responsibilities can lead to competitiveness which would in turn bring about corporate performance.

However, so little is known about the influence of philanthropic responsibility and its effect on competitiveness. Hence this study investigates the effect of philanthropic responsibility on competitiveness of private universities in Nigeria.

\section{PHILANTHROPIC RESPONSIBILITY}

By corporate philanthropy, we mean the direct, non-refundable donation of money, commodities, or services, as well as the use of workers' time, to assist a humanitarian cause or achieve a social goal" (Okaro \& Okafor, 2021). According to this definition, corporate philanthropy includes not only the company's voluntary contributions, but also the employees' voluntary activity and commitment to the achievement of a social goal. Positive or proactive social responsibility is a term that refers to a company's maximum involvement in fixing societal issues. In order to contribute to the community in which they work, it is critical for the company to participate in resolving some social problems and to make appropriate contributions through investments in the community's protection, the construction of socially needed objects, and the provision of scholarships to individuals and groups (Bello, 2020). The government has a critical role in encouraging corporate philanthropy. By enacting tax incentives, the government can encourage businesses to invest more money in general good causes.

Donations and sponsorships are the two most common types of corporate investment. In the context of socially responsible economic policy, Daellenbach, Seymour, and Webster (2020) identified these two types of investment as critical for tackling problems in the community and society in which the firm operates. It is vital to have a stimulating tax policy in order for the practise of socially responsible economy to emerge. According to Saidu (2018), establishing philanthropy as a strategic activity for a firm in the context of a socially responsible economy provides valuable, immaterial value and contributes to competitive advantage. As part of responsible community behaviour, every corporation should integrate philanthropy in their business policy. Companies can develop their identity and image through these efforts and ensure a competitive position (Adeniji, Osibanjo \& Abiodun, 2015; Su, \& Sauerwald, 2018).

Philanthropy also includes corporate initiatives focused at promoting human happiness or goodwill in response to societal expectations. Public relations, good citizenship, and community service are all duties that a company actively accepts.

\subsection{Competitiveness}

The concept of competitiveness has been a hot topic in the field of competitive strategies in recent years, and there has been a lot of debate about it. Nonetheless, defining competitiveness with precision is a challenging undertaking. On one hand, competitiveness has been defined as excessive returns, while on the other; it has been tied to capital market performance and expectations. However, in the field of competitive strategy and in the context of value creation, the most popular definition of competitiveness is whatever causes revenues to increase over expenses (Hakkak \& Ghodsi, 2015).

Competitiveness is a critical issue in today's dynamic corporate climate. A variety of perspectives on the factors that influence competitiveness have been suggested. According to Porter (1990), the profitability of a corporation is determined by the industry's attractiveness and the firm's relative position within it. According to this theory, strategy causes an organization's actions to be distinct from those of its competitors, and 
critical competences promote distinctiveness and diversity adoption, resulting in competitiveness for the business. The primary purpose of an organization's competitiveness strategy, based on its resources and capabilities, is to obtain competitiveness and establish a distinct position in the commercial market. The key to obtaining competitiveness is long-term competitiveness, which is based on identifying and perceiving client wants, focusing on the customer, and improving the process from the customer's point of view. Sustainable competitiveness is a type of competitiveness that capitalises on organisational competencies that are important to customers, are difficult to replicate and copy, and give competence and competitiveness to the business.

When a company's profit rate is higher than the industry's average, it is considered to be competitive, and when the high profit rate is maintained for several years, it is said to be sustainable competitiveness.

\subsection{Objective of the Study}

The aim of this study is to determine the degree to which philanthropic responsibility affects competitiveness of private institutions in Nigeria. As such the following hypothesis was deduced;

$\mathrm{H}_{0 \text { : }}$ Philanthropic responsibility has no significant effect on competitiveness

\section{MATERIALS AND METHODS}

The study focused on philanthropic responsibility and competitiveness of private institutions in Nigeria. The study was conducted amongst six private universities in Nigeria namely: Covenant University, Babcock University, Bowen University, Redeemers University, Mountain Top University and Afe Babalola University. The selected institutions have been in existence for over ten years as such were deemed suitable for the study. The study made use of questionnaire to obtain data from respondents. Random and convenience sampling techniques which is a type of probability and non-probability sampling technique was adopted to reach the target population. A sample size of 410 was used for the survey out of which 353 were utilized. The statistical package for social sciences (SPSS) was used to examine the data.

\section{RESULTS AND DISCUSSIONS}

In this context, discretionary (philanthropic) responsibility consists of community supports/services, employment of community members, provisions of grants/sponsorship, engagement of charitable activities. In other words, discretionary (philanthropic) responsibility is often seen as management tools to facilitate corporate objectives. In the discretionary (philanthropic) responsibility dimension, companies are expected to contribute money, facilities, and other resources to the communities.

Table 4.1 Frequency Distribution for Discretionary (philanthropic) responsibility

\begin{tabular}{|c|c|c|c|c|c|c|c|c|}
\hline \multirow[t]{2}{*}{$\mathrm{s} / \mathrm{n}$} & \multirow[t]{2}{*}{ Items } & \multicolumn{4}{|c|}{ Frequency and Percentage } & \multirow[t]{2}{*}{ Total } & \multirow[t]{2}{*}{ Mean } & \multirow[t]{2}{*}{ SD } \\
\hline & & $\begin{array}{l}\text { Strongly } \\
\text { Agree }\end{array}$ & Agree & Disagree & $\begin{array}{l}\text { Strongly } \\
\text { Disagree }\end{array}$ & & & \\
\hline 1 & $\begin{array}{l}\text { Community supports/ } \\
\text { services }\end{array}$ & $\begin{array}{l}88 \\
24.9 \% \\
\end{array}$ & $\begin{array}{l}115 \\
32.6 \% \\
\end{array}$ & $\begin{array}{l}128 \\
36.3 \%\end{array}$ & $\begin{array}{l}22 \\
6.2 \% \\
\end{array}$ & $\begin{array}{l}353 \\
100 \% \\
\end{array}$ & 2.238 & .898 \\
\hline 2 & $\begin{array}{l}\text { Engagement of } \\
\text { charitable activities }\end{array}$ & $\begin{array}{l}114 \\
32.3 \%\end{array}$ & $\begin{array}{l}127 \\
36 \%\end{array}$ & $\begin{array}{l}84 \\
23.8 \%\end{array}$ & $\begin{array}{l}28 \\
7.9 \% \\
\end{array}$ & $\begin{array}{l}353 \\
100 \%\end{array}$ & 3.068 & .931 \\
\hline 3 & $\begin{array}{l}\text { Provisions of } \\
\text { grants/sponsorship }\end{array}$ & $\begin{array}{l}126 \\
35.7 \%\end{array}$ & $\begin{array}{l}112 \\
31.7 \%\end{array}$ & $\begin{array}{l}100 \\
28.3 \%\end{array}$ & $\begin{array}{l}15 \\
4.2 \%\end{array}$ & $\begin{array}{l}353 \\
100 \%\end{array}$ & 3.139 & .894 \\
\hline 4 & $\begin{array}{l}\text { Employment of } \\
\text { community members }\end{array}$ & $\begin{array}{l}51 \\
14.4 \% \\
\end{array}$ & $\begin{array}{l}103 \\
29.2 \% \\
\end{array}$ & $\begin{array}{l}132 \\
37.4 \% \\
\end{array}$ & $\begin{array}{l}67 \\
19 \% \\
\end{array}$ & $\begin{array}{l}353 \\
100 \% \\
\end{array}$ & 2.104 & .873 \\
\hline \multicolumn{7}{|c|}{ Average Means Score } & 2.637 & 0.899 \\
\hline
\end{tabular}

Table 4.1 shows the measures of philanthropic responsibility for the selected private universities. From the table above, it was revealed that $88(24.9 \%)$ and $115(32.6 \%)$ of the respondents strongly agreed and agreed the selected institutions engaged in community supports/ services; $128(36.3 \%)$ disagreed, while $8(2 \%)$ of the respondents strongly disagree with the statement. This implies that majority of the staff of the selected private universities representing 57.5\% affirmed that they engage in community supports/ services.

It was also revealed that $114(32.3 \%)$ and $127(36 \%)$ of the respondents strongly agreed and agreed that the 
selected institutions are committed to charitable activities; $84(23.8 \%)$ disagreed, while $28(7.9 \%)$ of the respondents strongly disagree with the statement. This infers that the majority of the staff across various levels representing $68.3 \%$ facilitates the engagement of charitable activities.

However, $126(35.7 \%)$ and $112(31.7 \%)$ of the respondents strongly agree and agreed to the statement that the selected institutions provide grants/sponsorship to community members; 100 (28.3\%) disagreed, while $15(4.2 \%)$ strongly disagreed with the statement. This indicates that the majority of the staff of the selected private universities in Nigeria representing $67.4 \%$ ascertained that they engage in the provisions of grants/sponsorship.

It was also revealed that $51(14.4 \%)$ and $103(29.2 \%)$ of the respondents strongly agreed and agreed that the selected institutions are committed to the employment of community members; $132(37.4 \%)$ disagreed, while $67(19 \%)$ of the respondents strongly disagree with the statement. This infers that the majority of the staff across various levels representing $43.6 \%$ claimed that they engage in the employment of community members. This implies that the selected private institutions need to continually intensify their efforts in employing the community members.

The study found empirical evidence that shows managers and employees participate voluntarily to charitable activities in the local community. These findings confirm the theoretical claims of Sallam (2016), Oral, Cinar \& Chabchoub (2019). They claimed the importance of organisations in participating voluntarily to projects improving the quality of community life. The implication is that private institutions should continually and consistently act according to philanthropic and charitable society expectations.

Table 4.2: Factor Loading for Discretionary (philanthropic) responsibility in the selected private universities in Nigeria

\begin{tabular}{|l|l|l|l|l|l|l|}
\hline & $\begin{array}{l}\text { Factor } \\
\text { Loading }\end{array}$ & $\begin{array}{l}\text { Error } \\
\text { Variance }\end{array}$ & $\begin{array}{l}\text { Composite } \\
\text { Reliability }\end{array}$ & AVE & $\begin{array}{l}\text { Cronbach's } \\
\text { Alpha }\end{array}$ & $\begin{array}{l}\text { No. of } \\
\text { Indicators }\end{array}$ \\
\hline Indicators & $>0.7$ & $<0.5$ & $\geq 0.8$ & $\geq 0.5$ & $\geq 0.7$ & \\
\cline { 1 - 2 } $\begin{array}{l}\text { Discretionary } \\
\text { (DPR) }\end{array}$ & (philanthropic) & responsibility & 0.845 & 0.529 & 0.765 & 4 \\
\cline { 1 - 3 } DPR1 & 0.721 & 0.279 & & & & \\
\cline { 1 - 3 } & 0.748 & 0.252 & & & & \\
\hline DPR3 & 0.819 & 0.181 & & & & \\
\hline DPR4 & 0.822 & 0.178 & & & & \\
\hline
\end{tabular}

From the Table 4.2, it shows that all the constructs of the philanthropic responsibility and competitiveness have values higher than 0.80 and 0.70 , which means that they have composite internal consistency and Cronbach Alpha reliability respectively. The factor loadings for the specific measures of construct ranged between 0.721 and 0.822 . The instrument is adjudged reliable and valid since the fundamental requirement for the degree of fitness was satisfactorily met. None of the items had a loading factor lower than 0.6.

\section{CONCLUSION}

This paper presents a conceptual model where philanthropic responsibility can be used as a tool to enhance competitiveness. The model provides evidence that taking into account how philanthropic responsibility can positively affect how institutions are viewed and perceived which can positively or negatively affect an institution's productivity and performance levels, growth, development and ultimately competitiveness. Therefore, it is imperative that educational institutions ensure they provide philanthropic responsibility to increase the brand image which will result in the competitiveness.

\subsection{Limitation and Future Study}

Only six private institutions were covered in this study. Hence, there is limitation in scope which will not permit generalization of the findings. Also future studies can also carry out a comparative analysis between public and private educational institutions in the country. 


\section{ACKNOWLEDGEMENT}

The author of this article acknowledges Covenant University for full sponsorship of this research.

\section{REFRENCE LIST}

Adeniji, A. A., Osibanjo, A. O., \& Abiodun, A. J. (2015). Corporate Image: A Strategy for Enhancing Customer Loyalty and Profitability. Journal of South African Business Research, 1 12. Retrieved from http://eprints.covenantuniversity. edu.ng/8432/\#.XHfFkYgzaUk

Bello, I. (2020). Sustainable development goals (SDGs) for education in Nigeria: An examination of Etisalat corporate social responsibility in Nigeria's post-basic education sector. International Journal of Lifelong Education, 39(5-6), 562-575.

Boehe, D.M. and Cruz, L.B., 2010. Corporate social responsibility, product differentiation strategy and export performance. Journal of Business ethics, 91(2), pp.325-346.

Brin, P., Nehme, M. and Polančič, G., 2020. Corporate Social Responsibility as an Instrument of Increasing Country Competitiveness. Torun International Studies, 1(13), pp.131-150.

Daellenbach, K., Seymour, R. G., \& Webster, C. M. (2020). Exploring responsible global leadership in corporate-community transactions. In Research Handbook of Global Leadership. Edward Elgar Publishing.

Ganiyu, R. A., 2017. Customer satisfaction and loyalty: A study of interrelationships and effects in Nigerian domestic airline industry. Oradea journal of business and economics, 2(1), 7-20.

Hakkak, M., \& Ghodsi, M. (2015). Development of a sustainable competitive advantage model based on balanced scorecard. International Journal of Asian Social Science, 5(5), 298-308.

Ibidunni, A.S., Olokundun, M.A, Falola, H.O. and Ogunnaike O.O, (2018). Descriptive analysis of organizational knowledge utilization in Nigeria's telecommunication industry: A focus on managerial implications. Academy of Strategic Management Journal, 17(2), PP.1-7.

Igbekoyi, O.E. (2017). Causal effect of corporate social responsibility on value drivers in the Nigerian manufacturing sector. Journal of Emerging trends in Economics and Management Sciences, 8(3), pp.169-177.

Motilewa, D. B., \& Worlu, R. E. (2015). Corporate social responsibility as a tool for gaining competitive advantage. International Journal of Multidisciplinary Research and Review.

Ogbari, M. E., Dayo, A. T., \& Ibidunni, O. S. (2018). Concise Adoption of Generic Business Strategies, Virtues for Accomplishing: Corporate Mission in Multinational Firms in Nigeria. Canadian Social Science, 14(1), 9-19.

Okaro, S. C., \& Okafor, G. O. (2021). Corporate Social Responsibility in Nigeria. In Current Global Practices of Corporate Social Responsibility (pp. 525-541). Springer, Cham.

Oyewumi, O. R., Ogunmeru, O. A., \& Oboh, C. S. (2018). Investment in corporate social responsibility, disclosure practices, and financial performance of banks in Nigeria. Future Business Journal, 4(2), 195-205.

Saidu, N. (2018). A Synthesis of Corporate Social Responsibility Concept, As a Mechanism to Enhanced Organizational Reputation in Nigeria. Asian Finance \& Banking Review, 2(1), 30-36.

Salem, M. A., Shawtari, F. A., Shamsudin, M. F. \& Hussain, H. I. (2016). The relation between stakeholder"s integration and environmental competitiveness. Social Responsibility Journal, 12(4), 755-769.

Shabbir, M. S., \& Wisdom, O. (2020). The relationship between corporate social responsibility, environmental investments and financial performance: evidence from manufacturing companies. Environmental Science and Pollution Research, 1-12.

Su, W., \& Sauerwald, S. (2018). Does corporate philanthropy increase firm value? The moderating role of corporate governance. Business \& Society, 57(4), 599-635. 